\title{
ODWODNIENIE STREF BEZODPŁYWOWYCH MAŁEJ ZLEWNI MIEJSKIEJ
}

\author{
Władysław Matusiewicz, Grzegorz Wrzesiński ${ }^{\circledR}$ \\ Wydział Budownictwa i Inżynierii Środowiska, Szkoła Główna Gospodarstwa Wiejskiego w Warszawie, Warszawa
}

\begin{abstract}
STRESZCZENIE
Tereny w zlewni miejskiej nisko położone bez możliwości odpływu piętrzą wody powierzchniowe z opadów atmosferycznych, powodując podtopienia. Zakres podtopień zależy od natężenia deszczu, wielkości zlewni oraz odbiornika wód. Jednym ze sposobów odwodnienia jest gromadzenie wód w zbiornikach retencyjnych, a następnie wywożenie ich za pomocą cystern do odbiornika. Taki przypadek ma miejsce w środkowej części ulicy Podborskiej w Warszawie. Jest to rozwiązanie mało skuteczne, wymagające ciągłego opróżniania zbiorników. W tej sytuacji zaproponowano dwa alternatywne rozwiązania. Pierwsze polega na wprowadzeniu wód czystych do gruntu, a ścieki deszczowe do nowego zbiornika po drugiej stronie ulicy. Druga koncepcja przewiduje odprowadzenie wszystkich wód opadowych ze zlewni do istniejącej kanalizacji deszczowej parkingu i budynku administracyjnego, $\mathrm{z}$ jednoczesnym wykonaniem nowych zbiorników retencyjnych połączonych przewodem o średnicy $0,5 \mathrm{~m}$ z istniejącym systemem retencyjnym. Wody deszczowe ze zbiorników odprowadzane będą poprzez kanalizację deszczową parkingu samochodowego i separatora substancji ropopochodnych z bajpasem do istniejącej kanalizacji zlokalizowanej w alei Krakowskiej. Przewód kanalizacji o średnicy 0,4 m, położony pod dwupasmową jezdnią włączony jest do kanalizacji deszczowej o średnicy $1 \mathrm{~m}$. W celu zlikwidowania ograniczenia natężenia przepływu pod aleją Krakowską, zaproponowano wymianę odcinka przewodu kanalizacyjnego o średnicy $0,4 \mathrm{~m}$ na przewód o średnicy $0,8 \mathrm{~m}$. Umożliwi to w przyszłości odwodnienie nowych inwestycji budowlanych w tym rejonie. Wymiana przewodu wykonana będzie za pomocą technologii bezwykopowej. Rury betonowe zostaną usunięte $\mathrm{z}$ gruntu pod jezdnią siłownikami hydraulicznymi. $\mathrm{Z}$ drugiej strony jezdni, równolegle $z$ usuwaniem rur istniejących, powstały otwór poszerzany będzie przewiertem niesterowanym poziomym o średnicy $0,9 \mathrm{~m}, \mathrm{z}$ jednoczesnym wciskaniem nowych rur o średnicy $0,8 \mathrm{~m}$.
\end{abstract}

Słowa kluczowe: podtopienie, odwodnienie, kanalizacja deszczowa, strefa bezodpływowa, mała zlewnia miejska

\section{WSTĘP}

Intensywny rozwój budownictwa mieszkaniowego i usługowego na terenie dużych miast wkracza w obszary, na których brakuje systemów zagospodarowania wód opadowych i roztopowych. Wody z nowych utwardzonych nawierzchni, takich jak: dachy budynków i budowli, ulice, chodniki, parkingi itp., gromadzą się w miejscach najniżej położonych, powodując podtopienia i kałuże, oraz wlewają się do pomieszczeń podziemia (Matusiewicz, 2003a, b; Koda, Matusiewicz i Osiński, 2017). Często gęsta zabudowa zwiększająca nawierzchnie utwardzone powoduje, że istniejące kanalizacje deszczowe lub systemy retencyjne nie sa w stanie przyjąc wód opadowych z powodu zbyt małej przepustowości (Kotowski, 2011; Matusiewicz, 2011). W takim przypadku konieczna jest modernizacja systemów istniejących, budowa nowych lub wprowadzenie wód do gruntu (Mielcarzewicz, 1990; Sokołowski i Żbikowski, 1993; Edel, 2006; Lechowicz, Garbulewski,

${ }^{凶}$ grzegorz_wrzesinski@sggw.pl 
Król, Matusiewicz i Wrzesiński, 2014; Barszcz, 2017). Przykładem podtopienia ulic, budynków i parkingów wodami opadowymi i roztopowymi jest środkowy odcinek ulicy Podborskiej w Warszawie, który położony jest w najniższym punkcie terenu. Obszar ten nie ma klasycznego grawitacyjnego systemu odwodnienia. Dopływy z deszczy nawalnych z sasiednich ulic, posesji i targowiska tworzą tutaj kałuże trudne do pokonania przez ludzi i przejechania pojazdem samochodowym. Wykonany w tym miejscu przed 20 laty system retencyj- ny, składający się ze zbiornika otwartego i trzech studni podziemnych (rys. 1), jest mało skuteczny. Spiętrzone w nim ścieki deszczowe opróżniać można tylko za pomocą wozów asenizacyjnych. Należy zaznaczyć, że po deszczach nawalnych służby miejskie w pierwszej kolejności odwadniają zalane użytkowe pomieszczenia przyziemia obiektów mieszkalnych, a dopiero w drugiej kolejności odbywa się opróżnianie zbiorników retencyjnych z zalanych ulic czy parkingów, gdzie czas oczekiwania na wypompowanie wynosi często powyżej $5 \mathrm{~h}$ po opadzie.

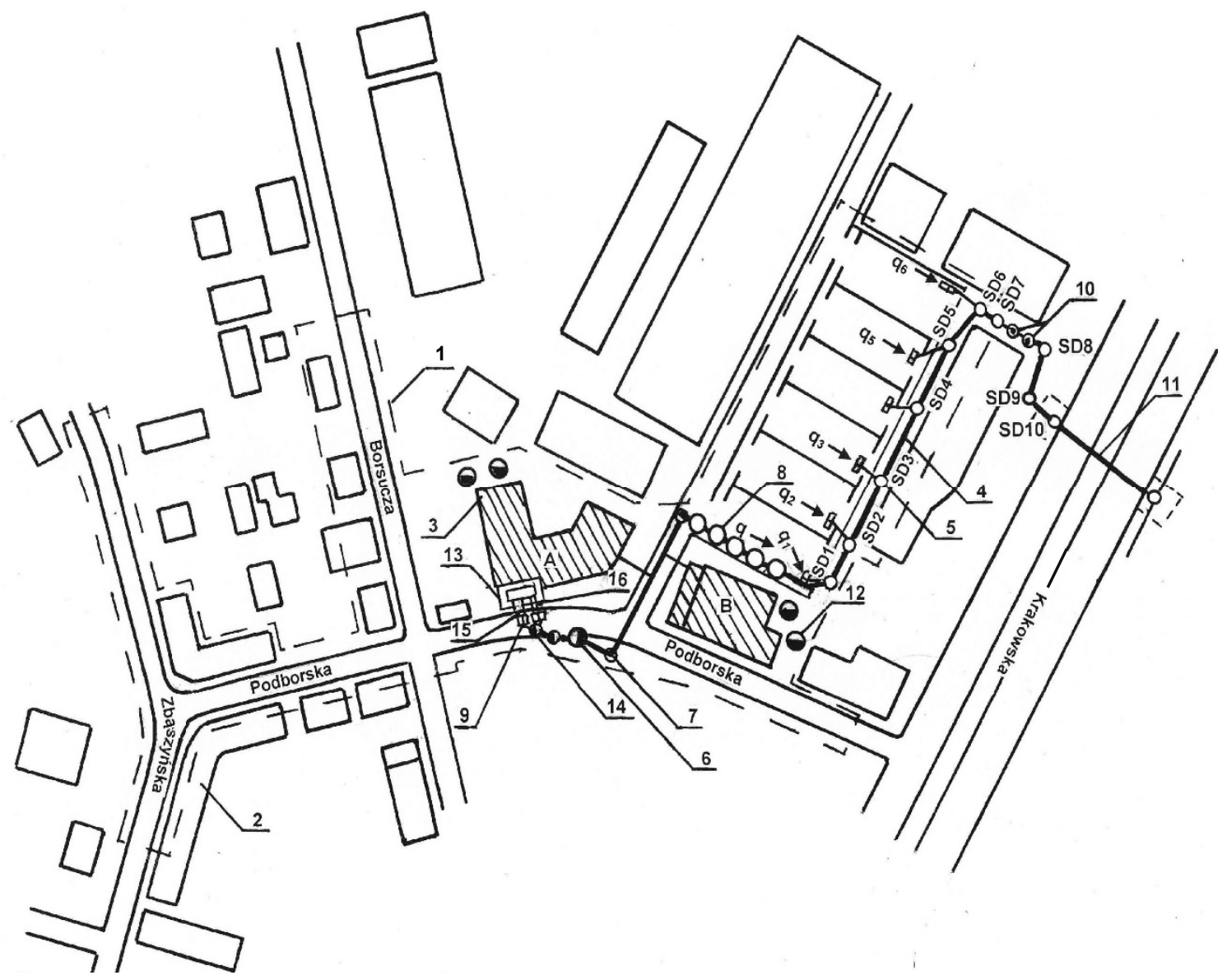

Rys. 1. Plan analizowanej małej zlewni miejskiej z lokalizacją odbiorników wód opadowych: 1 - zasięg zlewni, 2 - budynek, 3 - budynek projektowany, 4 - przewód kanalizacji deszczowej istniejący, 5 - studnia deszczowa parkingu istniejąca, 6 - studnia retencyjna istniejąca, 7 - studnia deszczowa projektowana, 8 - studnia retencyjna projektowana, 9-wpust deszczowy istniejący, 10 - separator substancji ropopochodnych, 11 - wymiana przewodu, 12 - studnia chłonna, 13 - zbiornik wód opadowych, 14 - studnia retencyjna istniejąca, 15 - kanał wlotowy, 16 - kanał wylotowy

Fig. 1. Analyzed small urban catchment with rainwater receivers location: 1 - catchment area, 2 - building, 3 - planned building, 4 - existing storm sewer pipe, 5 - existing rainwater well, 6 - existing retention well, 7 - planned rainwater well, 8 - planned retention well, 9 - existing rainwater inlet, 10 - separator of petroleum substances, 11 - pipe to exchange, 12 - absorbing well, 13 - rainwater reservoir, 14 - existing retention well, 15 - inlet channel, 16 - outlet channel 
W 2016 roku podmiot administracyjny, w ramach warunków zabudowy wykonania dwu budynków mieszkalnych czteropiętrowych A i B przy ulicy Podborskiej (rys. 1), wydał pozytywną decyzje pozwolenia na budowę, uzależniając ją od uregulowania przez inwestora problemu wód deszczowych z całej zlewni. Decyzja nakładała na inwestora obowiązek wykonania ujęcia i odprowadzenia wody $\mathrm{z}$ odwodnienia dachów projektowanych budynków A i B wraz z parkingami oraz dodatkowo odprowadzenia wody opadowej i roztopowej ze zlewni obejmujacej analizowany rejon. Istniejacy na terenie posesji otwarty zbiornik retencyjny ścieków przeznaczono do likwidacji (rys. 1). Analizując charakter zabudowy, warunki topograficzne i dokumentacje geotechniczną oraz dotychczasowe sposoby odwodnienia i miejsca zrzutu wód deszczowych w okolicy, zaproponowano wariantowe sposoby odwodnienia analizowanego rejonu. Zalecane w przypadku ulicy Podborskiej i okolic koncepcje odwadniania obiektów oraz terenów położonych w miejscach bezodpływowych będzie można wykorzystać przy realizowaniu nowych inwestycji.

\section{CHARAKTRYSTYKA OBIEKTU}

Projektowane budynki mieszkalne A i B położone są po północnej stronie ulicy Podborskiej. Powierzch- nia działki składająca się $\mathrm{z}$ dwóch części wynosi 0,2370 ha. Rozdziela ją droga wewnętrzna (rys. 1). Działka z budynkiem A ma powierzchnię 0,1331 ha, w tym: powierzchnia zabudowy 0,0569 ha, powierzchnia utwardzona 0,0181 ha, trawniki 0,0581 ha. Działka $\mathrm{z}$ budynkiem $\mathrm{B}$ ma powierzchnię 0,1039 ha, w tym: powierzchnia zabudowy 0,0386 ha, powierzchnia utwardzona 0,0241 ha, trawniki 0,0412 ha. Oprócz ulicy Podborskiej o powierzchni 0,2070 ha zlewnia obejmuje część ulicy Borsuczej o powierzchni 0,1080 ha i część ulicy Zbąszyńskiej o powierzchni 0,1820 ha. Najniżej położony punkt zlewni zlokalizowany jest w środkowej części ulicy Podborskiej. Analizowany rejon nie ma klasycznej kanalizacji deszczowej. Wody opadowe gromadzone sa w zbiorniku retencyjnym otwartym o wymiarach: długość $15 \mathrm{~m}$, szerokość $7 \mathrm{~m}$, głębokość $1,5 \mathrm{~m}$ i w trzech studniach retencyjnych krytych, bez odpływu. Pierwsza studnia o średnicy $1,2 \mathrm{~m}$ i głębokości 2,58 $\mathrm{m}$ znajduje się w jezdni ulicy Podborskiej. Druga o średnicy 1,2 m i głębokości $1,82 \mathrm{~m}$ oraz trzecia o średnicy $2,5 \mathrm{~m}$ i głębokości $3,15 \mathrm{~m}$ posadowione są $\mathrm{w}$ trawniku między jezdnią i chodnikiem (rys. 1 i 2). Zbiornik otwarty i studnie retencyjne tworza jeden połączony system. Objętość systemu wynosi $156,92 \mathrm{~m}^{3}$. Wody deszczowe odbierane są z istniejącej studni retencyjnej o średnicy

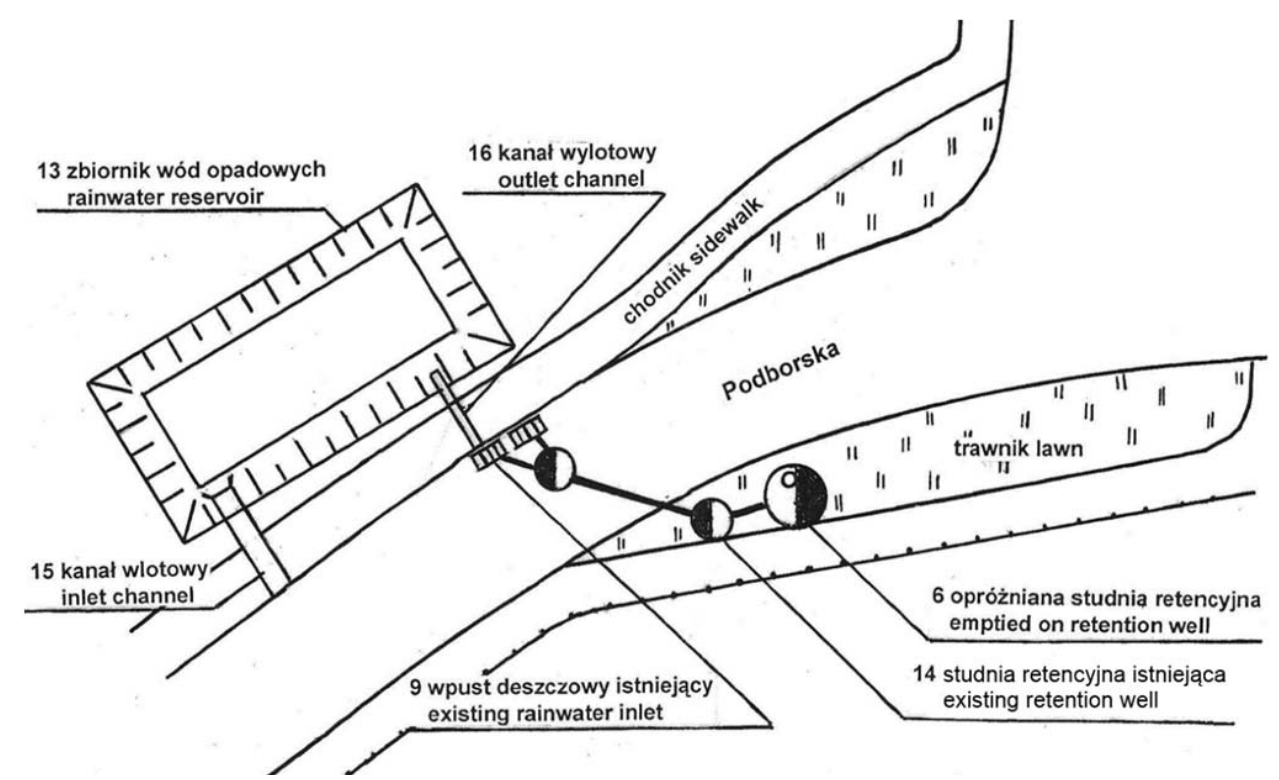

Rys. 2. Zbiornik i studnie retencyjne wód deszczowych: opis według rysunku 1

Fig. 2. Retention reservoir and rainwater retention wells: description according to Figure 1 
2,5 m samochodami cysternami (rys. 2) i wywożone do miejsca zrzutu.

\section{WARUNKI GEOTECHNICZNE}

W celu ustalenia warunków geotechnicznych podłoża gruntowego wykonano osiem otworów wiertniczych do głębokości 9 m p.p.t. i osiem badań sondą dynamiczną typu SL. Dla wszystkich warstw z każdego otworu przeprowadzono badania gruntów metodami laboratoryjnymi według norm polskich i unijnych (PN-B-02480:1986; PN-B-04481:1988; PN-EN ISO 14688-2:2006). Określono wilgotność i rodzaj gruntu, granice konsystencji, stopień zagęszczenia, współczynniki filtracji gruntów piaszczystych według metody Wiłuna (2013). Na postawie map archiwalnych i zdjęć lotniczych z 1946 roku stwierdzono, że analizowany teren położony jest w miejscu, gdzie wcześniej wydobywano glinę do wyrobów ceramicznych, głównie cegieł wypalanych na miejscu. Według informacji uzyskanych od mieszkańców tego rejonu, eksploatowano również piaski drobne polodowcowe do zapraw tynkarskich. W wykopach, po wyeksploatowaniu glin i piasków, gromadziły się wody opadowe oraz ścieki sanitarne wylewane $\mathrm{z}$ pobliskich zabudowań. Wsypywano również grunty spoiste nienadające się do wyrobu cegieł, a po drugiej wojnie światowej odpady z odgruzowania Warszawy.

$\mathrm{Z}$ badań wynika, że warunki geotechniczne na analizowanym terenie są zróżnicowane. $\mathrm{Na}$ działce z projektowanym budynkiem A podłoże do głębokości $1,0 \mathrm{~m}$ p.p.t. zbudowane jest $\mathrm{z}$ gruzu budowlanego nasypowego, pod którym do głębokości $4,1 \mathrm{~m}$ p.p.t. zalegaja grunty rodzime: pyły piaszczyste, gliny i gliny pylaste. Są one w stanie półzwartym i twardoplastycznym. Pod glinami do głębokości rozpoznania wynoszącej 9,0 m p.p.t., dominują piaski drobne i piaski średnie w stanie zagęszczonym. Na działce z budynkiem B do głębokości 5,5 m p.p.t. podłoże stanowi grunt nasypowy, w którym są kawałki cegieł zmieszanych z gruzem ceglanym o frakcji pospółki. Poniżej do głębokości $8,8 \mathrm{~m}$ p.p.t. zalegaja grunty rodzime: gliny pylaste w stanie miękkoplastycznym. Od głębokości 8,8 $\mathrm{m}$ do 9,0 $\mathrm{m}$ p.p.t. zdeponowane są piaski drobne w stanie zagęszczonym. Na obu działkach woda podziemna ma zwierciadło swobodne średnio na głębokości $8 \mathrm{~m}$ p.p.t. Spadek zwierciadła wody gruntowej ma kierunek południowo-wschodni. Określone laboratoryjnie współczynniki filtracji gruntów mineralnych piaszczystych wynoszą: piaski drobne $k_{10}=1,1 \cdot 10^{-5}-7,45 \cdot 10^{-5} \mathrm{~m} \cdot \mathrm{s}^{-1}$, piaski średnie $k_{10}=4,2 \cdot 10^{-5}-1,8 \cdot 10^{-4} \mathrm{~m} \cdot \mathrm{s}^{-1}$.

\section{ZAŁOŻENIA DO OBLICZEŃ}

W ramach rozwiązania problemów podtopień w analizowanej zlewni, zaproponowano dwie koncepcje odwodnienia. Pierwsza polega na wprowadzeniu wód czystych do gruntu, a ścieki deszczowe do nowego zbiornika po drugiej stronie ulicy. Druga przewiduje odprowadzenie wszystkich wód opadowych ze zlewni do istniejącej kanalizacji deszczowej parkingu i budynku administracyjnego, $\mathrm{z}$ jednoczesnym wykonaniem nowych zbiorników retencyjnych połączonych przewodem o średnicy $0,5 \mathrm{~m} \mathrm{z}$ istniejącym systemem retencyjnym. Wody deszczowe ze zbiorników odprowadzane będą poprzez kanalizację deszczową parkingu samochodowego i separatora substancji ropopochodnych z bajpasem do istniejącej kanalizacji zlokalizowanej w alei Krakowskiej. Obliczenia wykonano dla opadu o prawdopodobieństwie $20 \%$, czasie trwania 15 min i natężeniu deszczu $131 \mathrm{dcm}^{3} \cdot \mathrm{s}^{-1} \cdot \mathrm{ha}^{-1}$. W tych warunkach system działać będzie grawitacyjnie za wyjątkiem dwu odcinków przewodu o średnicy $0,3 \mathrm{~m}$, gdzie przepływ będzie pod ciśnieniem.

\section{KONCEPCJA MODERNIZACJI SYSTEMU RETENCYJNEGO}

Z powodu likwidacji istniejącego otwartego zbiornika retencyjnego wód deszczowych, podmiot decyzyjny zaproponował wykonanie nowego zbiornika otwartego, położonego na działce po drugiej stronie ulicy Podborskiej (rys. 3). Według tej koncepcji znajdujące się w obecnym systemie odwodnienia trzy studnie retencyjne pozostaną i będą włączone do proponowanego zbiornika retencyjnego (rys. 3). System ten retencjonować będzie ścieki deszczowe z dotychczasowej zlewni oraz dodatkowo wody $\mathrm{z}$ odwodnienia przewidywanych parkingów na posesjach $\mathrm{z}$ budynkami A i B. Do odbioru wód z dachów budynków 


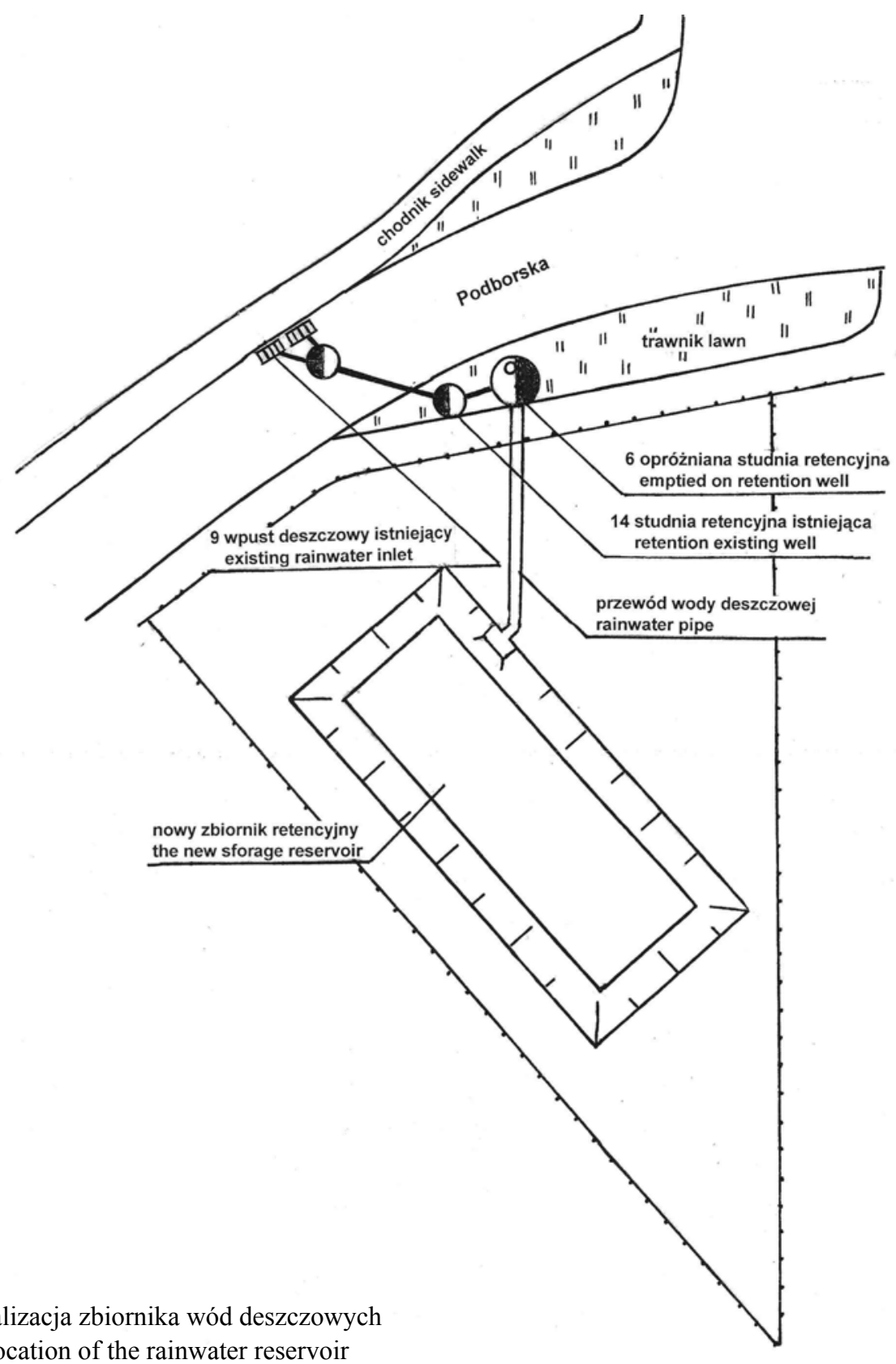

Rys. 3. Nowa lokalizacja zbiornika wód deszczowych

A i B zaproponowano studnie chłonne położone na posesji własnej (rys. 1). W ramach ustalenia wymiarów nowego zbiornika $\left(Q_{Z B}\right)$ czasowo piętrzącego ścieki deszczowe oraz objętości $\left(Q_{C H}\right)$ i ilości studni chłonnych $(x)$ określono: powierzchnię zlewni cząstkowych $\left(F_{C Z}\right)$, rodzaje nawierzchni, natężenie deszczu $(q)$ i spływ ze zlewni $\left(Q_{Z}\right)$ przy opadzie o określonym prawdopodobieństwie występowania $(p)$.

\section{Nowy zbiornik retencyjny}

1. Objętość zbiornika $Q_{Z B}$ :

$Q_{Z B}=Q_{Z L} \cdot t_{o}=\left(Q_{o}+Q_{P}+Q_{B}+Q_{Z}\right) \cdot t_{o}\left[\mathrm{~m}^{3}\right]$

gdzie:

$Q_{Z L}-$ spływ całkowity ze zlewni $\left[\mathrm{m}^{3} \cdot \mathrm{s}^{-1}\right]$;

$t_{o} \quad-$ czas trwania opadu $[\mathrm{s}]$; 
$Q_{o}$ - spływ deszczowy z terenu projektowanego osiedla bez uwzględnienia powierzchni dachów $\left[\mathrm{m}^{3} \cdot \mathrm{s}^{-1}\right]$

$Q_{P}-$ spływ deszczowy ze zlewni ulicy Podborskiej $\left[\mathrm{m}^{3} \cdot \mathrm{s}^{-1}\right]$

$Q_{B}-$ spływ deszczowy ze zlewni ulicy Borsuczej $\left[\mathrm{m}^{3} \cdot \mathrm{s}^{-1}\right]$

$Q_{Z}$ - spływ deszczowy ze zlewni ulicy Zbąszyńskiej $\left[\mathrm{m}^{3} \cdot \mathrm{s}^{-1}\right]$.

2. Przyjęto wartości: $Q_{o}=0,0218 \mathrm{~m}^{3} \cdot \mathrm{s}^{-1}, Q_{P}=0,0299$ $\mathrm{m}^{3} \cdot \mathrm{s}^{-1}, Q_{B}=0,0174 \mathrm{~m}^{3} \cdot \mathrm{s}^{-1}, Q_{Z}=0,0269 \mathrm{~m}^{3} \cdot \mathrm{s}^{-1}$, $t_{o}=900 \mathrm{~s}$ i obliczono: $Q_{Z B}=0,096 \mathrm{~m}^{3} \cdot \mathrm{s}^{-1} \cdot 900 \mathrm{~s}=$ $=86,4 \mathrm{~m}^{3}$.

Zaproponowano zbiornik o przekroju trapezowym o wymiarach $(L \times B \times W): 15 \times 10 \times 1,5 \mathrm{~m}$, nachyleniu skarp $1: 1$ i objętości $228 \mathrm{~m}^{3}$ (rys. 3).

\section{Studnia chłonna}

1. Wydatek studni chłonnej:

$$
Q_{C H}=4 \cdot \pi \cdot r \cdot h \cdot k\left[\mathrm{~m}^{3} \cdot \mathrm{s}^{-1}\right]
$$

gdzie:

$r$ - promień studni $[\mathrm{m}]$;

$h$ - wysokość piętrzenia do dna studni [m];

$k$ - współczynnik filtracji gruntu nasyconego $\left[\mathrm{m}^{3} \cdot \mathrm{s}^{-1}\right]$.

2. Natężenie deszczu według prawdopodobieństwa występowania:

$$
q=\frac{470 \cdot \sqrt[3]{c}}{t^{0,67}}\left[\mathrm{~m}^{3} \cdot \mathrm{s}^{-1} \cdot \mathrm{m}^{-2}\right]
$$

gdzie:

$c$ - częstotliwość deszczu $c=100 / p$ [lata];

$p$-prawdopodobieństwo pojawiania się deszczu [\%].

3. Spływ wód deszczowych z powierzchni dachu budynku A:

$$
Q=q \cdot F \cdot \psi\left[\mathrm{m}^{3} \cdot \mathrm{s}^{-1}\right]
$$

gdzie:

$F$ - powierzchnia dachu $\left[\mathrm{m}^{2}\right]$,

$\psi$ - współczynnik spływu powierzchniowego [-].
4. Przyjęto: $r=1,25 \mathrm{~m}, h=3,3 \mathrm{~m}, k=6,4 \cdot 10^{-5} \mathrm{~m} \cdot \mathrm{s}^{-1}$, $t=15 \mathrm{~min}, p=20 \%, c=5$ lat, $\psi=0,9, F=569 \mathrm{~m}^{2}$ i obliczono: $q=\frac{470 \cdot \sqrt[3]{5}}{15^{0,67}}=1,31 \cdot 10^{-5} \mathrm{~m}^{3} \cdot \mathrm{s}^{-1} \cdot \mathrm{m}^{-2}$ $Q=1,31 \cdot 10^{-5} \cdot 569 \cdot 0,9=6,709 \cdot 10^{-3} \mathrm{~m}^{3} \cdot \mathrm{s}^{-1}$ $Q_{C H}=4 \cdot 3,14 \cdot 1,25 \cdot 3,3 \cdot 6,4 \cdot 10^{-5}=3,32 \cdot 10^{-3}$ $\mathrm{m}^{3} \cdot \mathrm{s}^{-1}$

$Q_{C H}=3,32 \cdot 10 \mathrm{~m}^{3} \cdot \mathrm{s}^{-1}<Q=6,709 \cdot 10^{-3} \mathrm{~m}^{-3} \cdot \mathrm{s}^{-1}$

Liczba studni $x=Q / Q_{C H}=6,709 \cdot 10^{-3}: 3,32 \cdot 10^{-3}=$ $=1,992$ studni $\approx 2$ studnie.

Przyjęto dwie studnie chłonne do odwodnienia budynku A i dwie studnie w przypadku budynku B. Konstrukcję studni chłonnej pokazano na rysunku 4.

Nowy zbiornik retencyjny (rys. 3) bez odbiornika wód deszczowych będzie wymagać opróżniania za pomocą pojazdów asenizacyjnych. Wówczas w stosunku do obecnego sposobu odwodnienia ulic Podborskiej,

\section{m n.p.m.}

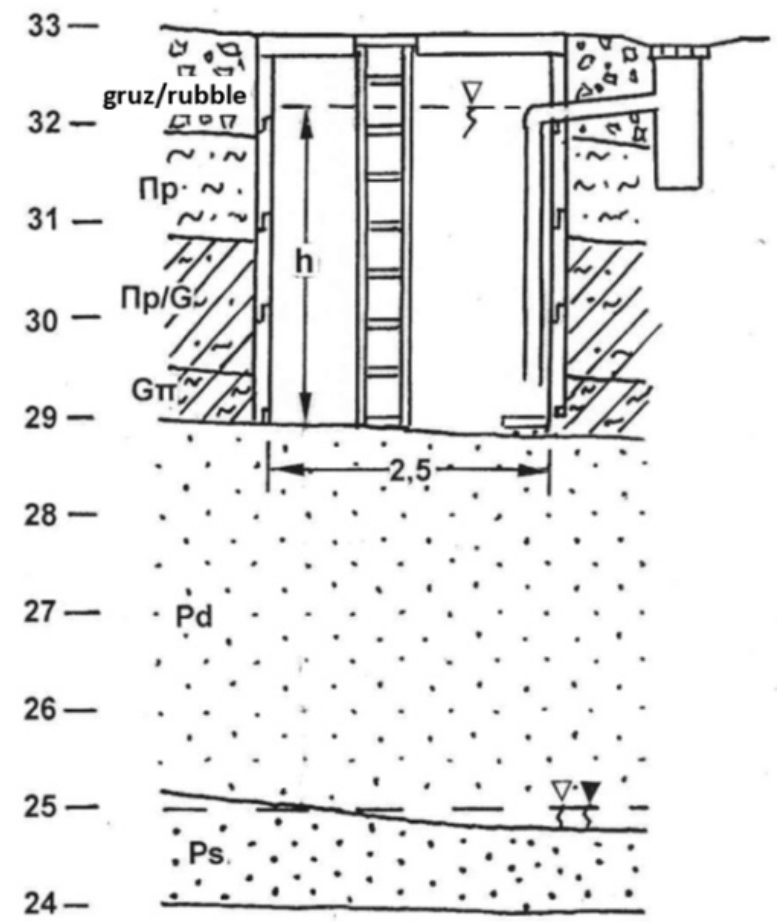

Rys. 4. Studnia chłonna

Fig. 4. Absorbing well 
Zbąszyńskiej i Borsuczej (rys. 2) praktycznie zmieni się tylko lokalizacja, a objętość zbiornika będzie większa (rys. 3).

\section{KONCEPCJA KANALIZACJI ZE ZRZUTEM DO MIEJSKIEJ SIECI DESZCZOWEJ}

Istniejący retencyjny sposób gromadzenia wód deszczowych (rys. 2) oraz jego nowa wersja (rys. 3) wymagają opróżniania urządzeń retencyjnych za pomocą cystern. Rozwiązania takie powoduja, że po deszczach nawalnych o objętości powyżej maksymalnego poziomu piętrzenia w zbiornikach retencyjnych, wody zalewają jezdnię i chodniki. Tworzą kałuże i po powierzchni terenu wpływają wjazdami do garaży i innych pomieszczeń przyziemia. Zbiorniki retencyjne są opróżniane po kilku godzinach od ustapienia opadu. Koszty naprawy zniszczeń mienia, osuszenia ścian fundamentowych i posadzek oraz wywozu wody są duże.

W celu wyeliminowania podtopień i obniżenia kosztów uciążliwego wywozu wód $\mathrm{z}$ analizowanego obszaru, zaproponowano koncepcję odwodnienia z wykorzystaniem działającej kanalizacji deszczowej parkingu przyległego do posesji dwu projektowanych budynków A i B (rys. 1). Kanalizacja parkingu wyposażona jest w sześć studni deszczowych o średnicy $d=1,2 \mathrm{~m}$ i sześć wpustów deszczowych oraz w separator substancji ropopochodnych. Odbiornikiem jest kolektor deszczowy o średnicy $d=1 \mathrm{~m}$ znajdujący się w alei Krakowskiej.

Proponowana kanalizacja deszczowa o długości $l=264 \mathrm{~m}$ składać się będzie z czterech odcinków:

- Pierwszym odcinkiem jest istniejący system trzech studni retencyjnych pionowych z dwoma ulicznymi wpustami deszczowymi, a zbiornik otwarty będzie zlikwidowany (rys. 2). Nowy odcinek kanalizacji deszczowej o długości $l=113,5 \mathrm{~m}$, średnicy $d=0,5 \mathrm{~m}$ oraz spadku $i=5,1 \%$ (rys. 5), zlokalizowany będzie między istniejącymi wpustami deszczowymi w ulicy Podborskiej a przekrojem I. Przewidziano jeden dodatkowy wpust uliczny, dwie nowe studnie deszczowe o średnicy $d=1,2 \mathrm{~m}$ i pięć studni retencyjnych SR o średnicy $d=2,5 \mathrm{~m}$. Studnie retencyjne są przepływowe, połączone między sobą rurami o średnicy $d=0,5 \mathrm{~m}$ i długości $l=0,4 \mathrm{~m}$ (rys. 5). Ich podstawowym przeznaczeniem jest czasowe spiętrzenie nadmiaru wód deszczowych w sytuacji

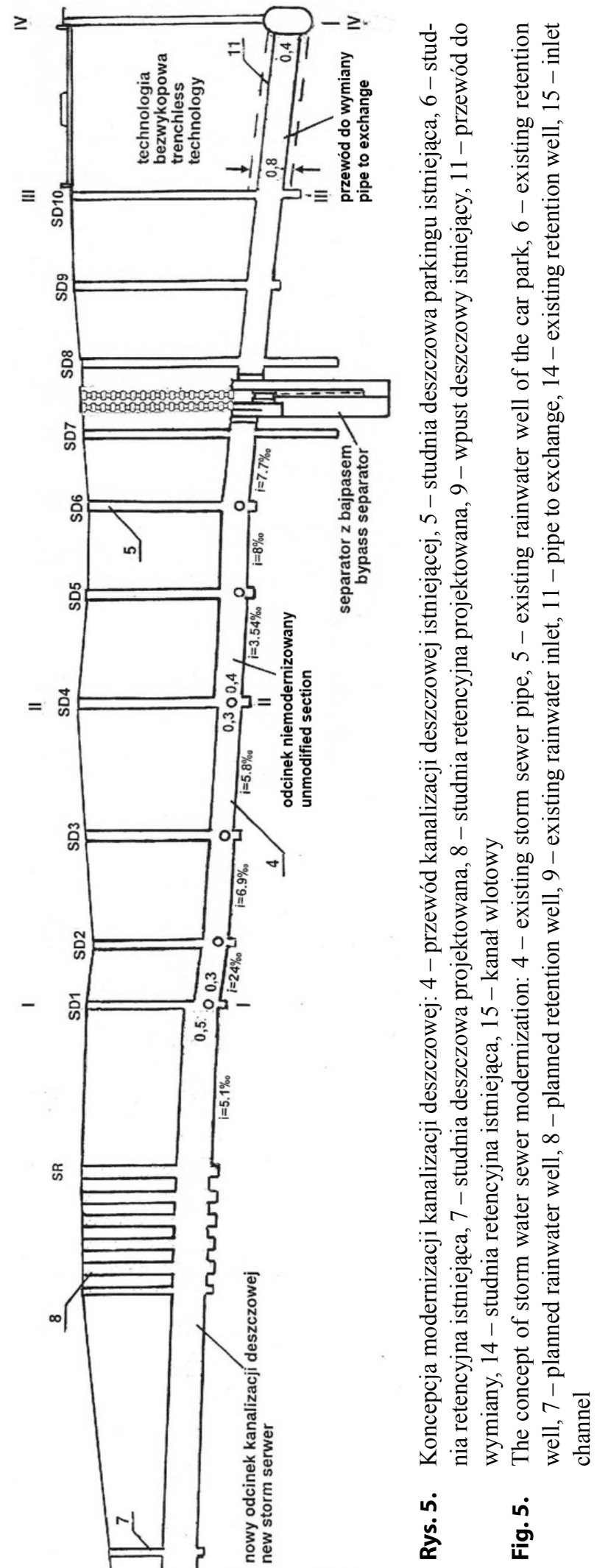


nadzwyczajnej, np. po opadach burzowych kolejno po sobie wystepujących i całkowitym tymczasowym wypełnieniu głównego odbiornika o średnicy $d=1 \mathrm{~m}$, zlokalizowanego w ulicy Aleja Krakowska (rys. 5).

- Drugim jest 34-metrowy odcinek kanalizacji deszczowej parkingu o średnicy $d=0,3 \mathrm{~m}$ oraz średnim spadku $i=12,23 \%$. Jest przedłużeniem proponowanego odcinka nowego o średnicy $d=0,5 \mathrm{~m}$. Położony jest między I i II przekrojem. W jego skład wchodzą cztery studnie deszczowe SD1, SD2, SD3 i SD4. Na początku odcinka w studni SD1 występuje zwężenie średnicy z $d=0,5 \mathrm{~m}$ do $d=0,3 \mathrm{~m}$, a na końcu odcinka rozszerzenie średnicy $\mathrm{z} d=0,3 \mathrm{~m}$ do $d=0,4 \mathrm{~m}$ (rys. 5). Do każdej z wymienionych studni włączone są odpływy z krat ściekowych odprowadzające wody deszczowe $\mathrm{z}$ poszczególnych fragmentów parkingu (rys. 1).

- Odcinek trzeci kanalizacji parkingu ma średnicę $d=0,4 \mathrm{~m}$ oraz średni spadek $i=6,41 \%$. Położony jest między II a III przekrojem. Ma długość $l=116 \mathrm{~m}$. Składa się z siedmiu studni deszczowych SD4, SD5, SD6, SD7, SD8, SD9 i SD10, przy czym tylko do studni SD4, SD5 i SD6 włączone są odpływy z segmentów odwadniających parking. Długości tych odcinków wynoszą odpowiednio 17 i 15 m (rys. 5). Po modernizacji długość przewodu o średnicy $d=0,4 \mathrm{~m}$ między przekrojami II i III będzie wynosić $l=87 \mathrm{~m}$. Na odcinku tym znajduje się jednokomorowy separator substancji ropopochodnych, który zastapiony zostanie na separator dwukomorowy $\mathrm{z}$ bajpasem i koalescencyjnym wkładem pochłaniającym (rys. 5 i 6 ).

- Modernizacja odcinka czwartego, zlokalizowanego pod aleją Krakowska, polega na wymianie przewodu deszczowego ze średnicy $d=0,4 \mathrm{~m}$ na przewód o średnicy $d=0,8 \mathrm{~m}$, który położony jest między III a IV przekrojem (rys. 5). Ma długość $l=29 \mathrm{~m}$ i spadek $i=7,7 \%$. Włączony jest do przewodu deszczowego o średnicy $d=1 \mathrm{~m}$. Wymiane rur proponuje się przeprowadzić za pomoca technologii bezwykopowej (rys. 7). Rury betonowe zostaną wyciagnięte $\mathrm{z}$ gruntu pod jezdnią siłownikami hydraulicznymi. $Z$ drugiej strony jezdni, równolegle $\mathrm{z}$ usuwaniem rur istniejących, powstały otwór poszerzany będzie przewiertem za pomoca wiertła ślimakowego o średnicy $d=0,9 \mathrm{~m}, \mathrm{z}$ jednoczesnym wciskaniem nowych rur o średnicy $d=0,8 \mathrm{~m}$.

\section{Hydrauliczne warunki pracy modernizowanego odcinka kanalizacji deszczowej}

Celem obliczeń hydraulicznych jest sprawdzenie przepustowości istniejącej kanalizacji deszczowej parkingu, do której włączony będzie nowy odcinek (rys. 5). Wstępna analiza proponowanych rozwiązań z uwzględnieniem narzuconych przez inwestora ograniczeń (brak zgody na wymianę rur o średnicy $d=$ $=0,3 \mathrm{~m}$ na rury o większej średnicy) wykazała, że dla

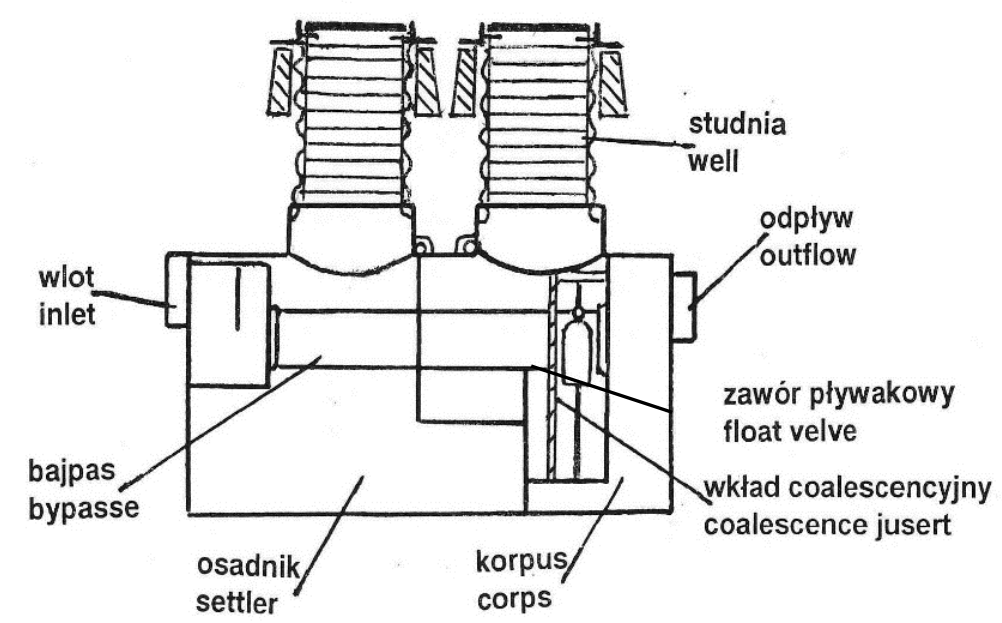

Rys. 6. Dwukomorowy separator substancji ropopochodnych $\mathrm{z}$ bajpasem

Fig. 6. Two-chamber separator of petroleum substances with bypass 


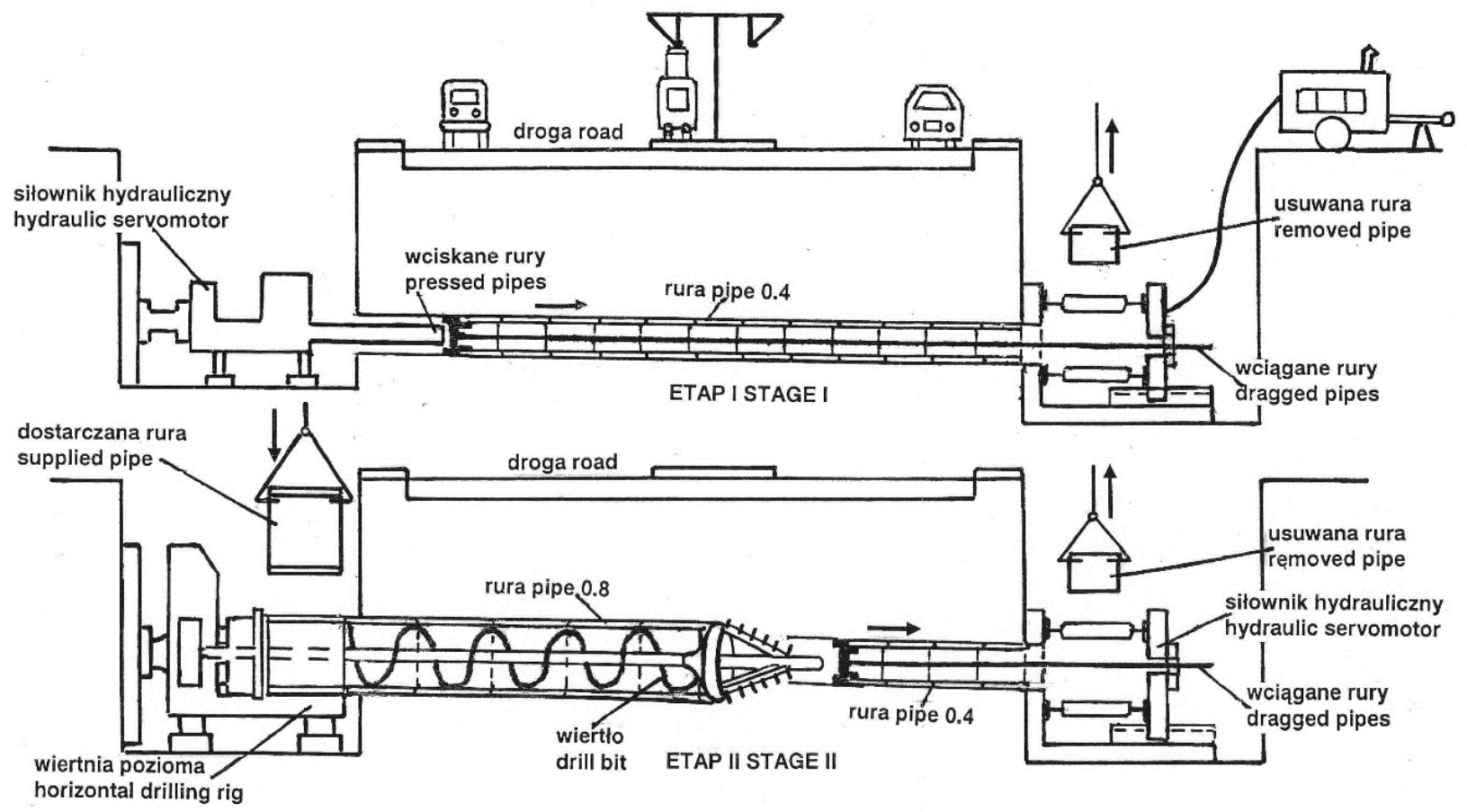

Rys. 7. Technologia bezwykopowa wymiany rur

Fig. 7. Trenchless pipe replacement technology

przyjętych parametrów dopływów niektóre odcinki systemu deszczowego pracować będą $\mathrm{w}$ systemie grawitacyjnym, a część odcinków w systemie podciśnieniowym.

\section{Natężenie przepływu w systemie grawitacyjnym}

1. Spływ deszczowy ze zlewni obliczono według wzoru:

$Q_{Z L}=\left(Q_{O D}+Q_{P}+Q_{B}+Q_{Z}+Q_{S D}\right)\left[\mathrm{m}^{3} \cdot \mathrm{s}^{-1}\right]$

gdzie:

$Q_{O D}-$ spływ deszczowy $\mathrm{z}$ terenu projektowanego osiedla z uwzględnieniem powierzchni dachów $\left[\mathrm{m}^{3} \cdot \mathrm{s}^{-1}\right]$

$Q_{P}-$ spływ deszczowy ze zlewni ulicy Podborskiej $\left[\mathrm{m}^{3} \cdot \mathrm{s}^{-1}\right]$

$Q_{B}$ - spływ deszczowy ze zlewni ulicy Borsuczej $\left[\mathrm{m}^{3} \cdot \mathrm{s}^{-1}\right]$

$Q_{Z}$ - spływ deszczowy ze zlewni ulicy Zbąszyńskiej $\left[\mathrm{m}^{3} \cdot \mathrm{s}^{-1}\right]$

$Q_{S D}-$ spływ deszczowy z poszczególnych sektorów kanalizacji deszczowej parkingu $\left[\mathrm{m}^{3} \cdot \mathrm{s}^{-1}\right]$.
2. Natężenie przepływu $\mathrm{w}$ analizowanych czterech hydraulicznych przekrojach obliczeniowych według Chézy’ego (Kubrak i Kubrak, 2000):

$Q_{o}=F_{o} \cdot V_{o}=$

$$
=\frac{\Pi \cdot d^{2}}{4} \cdot \frac{1}{2} \cdot \frac{1}{n} \cdot\left(\frac{d}{4}\right)^{0,167} \cdot \sqrt{d \cdot i}\left[\mathrm{~m}^{3} \cdot \mathrm{s}^{-1}\right]
$$

gdzie:

$F_{o}$ - powierzchnia przekroju rury $\left[\mathrm{m}^{2}\right] ;$

$V_{o}$ - prędkość przepływu przy pełnym napełnieniu średnicy rury $\left[\mathrm{m} \cdot \mathrm{s}^{-1}\right]$;

$d$ - średnica rury [m];

$n$ - współczynnik szorstkości rury [-];

$i$ - spadek kanału [\%o].

3. Prędkość przepływu obliczono według Chézy’ego:

$$
V_{o}=\frac{1}{2} \cdot \frac{1}{n} \cdot\left(\frac{d}{4}\right)^{0,167} \cdot \sqrt{d \cdot i}\left[\mathrm{~m}^{3} \cdot \mathrm{s}^{-1}\right]
$$

gdzie: $d, n, i$ według równania (6). 
Matusiewicz, W., Wrzesiński, G. (2018). Odwodnienie stref bezodpływowych małej zlewni miejskiej. Acta Sci. Pol. Architectura, 17 (3), 131-144. doi: 10.22630/ASPA.2018.17.3.35

4. Natężenie i prędkość przepływu w rurociagach na podstawie krzywej sprawności przewodu kołowego obliczono następująco. Znając ilości wód deszczowych dopływających do kanalizacji, określono wielkości $Q_{Z L} / Q_{o}$ i $V / V_{o}$. Dla uzyskanych wyników z krzywej sprawności przewodu kołowego (Kubrak i Kubrak, 2000) wyznaczono rzeczywistą prędkość przepływu w przewodzie. Wyniki obliczeń hydraulicznych proponowanej kanalizacji deszczowej działającej w systemie grawitacyjnym zestawiono $\mathrm{w}$ tabeli.

Tabela. Parametry hydrauliczne proponowanej kanalizacji deszczowej

Table. Hydraulic parameters of the proposed storm-sewer

\begin{tabular}{|c|c|c|c|c|c|c|c|}
\hline \multirow{3}{*}{$\begin{array}{l}\text { Parametry hydrauliczne } \\
\text { Hydraulic parameters }\end{array}$} & \multicolumn{7}{|c|}{ Przekroje obliczeniowe - Cross sections } \\
\hline & SR-SD1 & SD1-SD2 & SD2-SD3 & SD3-SD4 & SD4-SD5 & SD5-SD6 & SD6-SD10 \\
\hline & \multicolumn{7}{|c|}{ Przepływ grawitacyjny - Gravity flow } \\
\hline $\begin{array}{l}\text { Średnica rury, } d[\mathrm{~m}] \\
\text { Pipe diameter }\end{array}$ & 0,5 & 0,3 & 0,3 & 0,3 & 0,4 & 0,4 & 0,4 \\
\hline $\begin{array}{l}\text { Długość odcinka, } L[\mathrm{~m}] \\
\text { Section length }\end{array}$ & 30 & 10 & 17,5 & 22,5 & 17 & 15 & 52 \\
\hline $\begin{array}{l}\text { Spadek kanału, } i[\% \text { ] } \\
\text { Slope channel }\end{array}$ & 5,1 & 24,0 & 6,9 & 5,8 & 3,54 & 8,0 & 7,7 \\
\hline $\begin{array}{l}\text { Max. objętość przepływu, } \\
Q_{o}\left[\mathrm{~m}^{3} \cdot \mathrm{s}^{-1}\right] \\
\text { Max. flow capacity }\end{array}$ & 0,318 & 0,177 & 0,095 & 0,096 & 0,148 & 0,220 & 0,216 \\
\hline $\begin{array}{l}\text { Objętość przepływu, } q \\
{\left[\mathrm{~m}^{3} \cdot \mathrm{s}^{-1}\right]} \\
\text { Flow capacity }\end{array}$ & 0,108 & 0,113 & 0,120 & 0,129 & 0,138 & 0,145 & 0,150 \\
\hline $\begin{array}{l}\text { Prędkość przepływu, } V_{o} \\
{\left[\mathrm{~m} \cdot \mathrm{s}^{-1}\right]} \\
\text { Flow rate }\end{array}$ & 1,62 & 2,50 & 1,34 & 1,35 & 1,18 & 1,75 & 1,72 \\
\hline $\begin{array}{l}\text { Prędkość przepływu, } V \\
{\left[\mathrm{~m} \cdot \mathrm{s}^{-1}\right]} \\
\text { Flow rate }\end{array}$ & 1,41 & 2,63 & $>\max$ & $>\max$ & 1,37 & 1,83 & 1,84 \\
\hline
\end{tabular}

Przepływ pod ciśnieniem - Flow under pressure

Wysokość wody górnej,
$H+i \cdot L[\mathrm{~m}]$
0,6
0,8

Height of upper water

Wysokość wody dolnej,

$\begin{array}{lllll}h[\mathrm{~m}] & - & - & 0,3 & 0,3\end{array}$

Height of bottom water

Prędkość przepływu, $V_{o}$

\begin{tabular}{llllll}
{$\left[\mathrm{m} \cdot \mathrm{s}^{-1}\right]$} & - & & - & 1,712 & 1,953 \\
\hline
\end{tabular}

Flow rate

Max. objętość przepływu,

$Q_{o}\left[\mathrm{~m}^{3} \cdot \mathrm{s}^{-1}\right]$

$0,121>0,120 \quad 0,138>0,129$

Max. flow capacity 


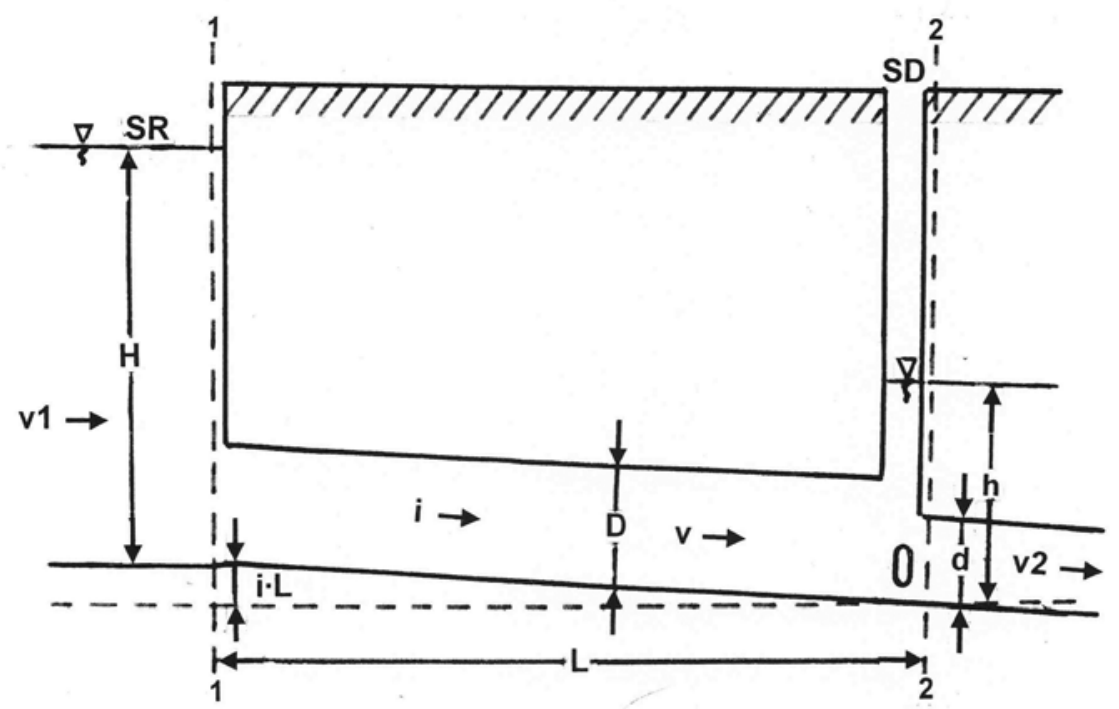

Rys. 8. Schemat obliczeniowy kanalizacji deszczowej w warunkach pod ciśnieniem: $L$ - długość odcinka [m]; $i$ - spadek przewodu [\%o]; $H+i \cdot L$ - wysokość spiętrzenia wody górnej [m]; $h$-wysokość spiętrzenia wody dolnej $[\mathrm{m}] ; D, d$-średnice rur $[\mathrm{m}] ; n$-współczynnik szorstkości rury $\left[\mathrm{m}^{-1 / 3} \cdot \mathrm{s}\right] ; V, V 1, V 2$ - prędkości przepływu $\left[\mathrm{m} \cdot \mathrm{s}^{-1}\right]$

Fig. 8. Scheme of rainwater sewage system under pressure: $L-\operatorname{section}$ length $[\mathrm{m}] ; I-$ slope channel $[\% 0] ; H+i \cdot L$ - height of upper water [m]; $h$ - height of bottom water [m]; $D ; d$-pipes diameter, $n$ - roughness coefficient $\left[\mathrm{m}^{-1 / 3} \cdot \mathrm{s}\right] ; V, V 1, V 2-$ flow velocity $\left[\mathrm{m} \cdot \mathrm{s}^{-1}\right]$

\section{Natężenie przepływu pod ciśnieniem}

1. Prędkość przepływu:

$$
\begin{gathered}
V=\sqrt{\frac{2 \cdot \mathrm{g} \cdot(H+i \cdot L-h)}{1+\xi_{w l}+\frac{8 \cdot \mathrm{g}}{c^{2}} \cdot \frac{L}{d}}}\left[\mathrm{~m}^{3} \cdot \mathrm{s}^{-1}\right] \\
c=\frac{1}{n} \cdot R_{h}^{\frac{1}{6}}[-]
\end{gathered}
$$

gdzie:

$c$ - współczynnik prędkości do wzoru Manninga [-];

$R_{h}-$ promień hydrauliczny rury $[\mathrm{m}] ;$

$\xi_{w l}-$ współczynnik strat na wlocie [-];

pozostałe oznaczenia według rysunku $8 \mathrm{i}$ tabeli.

2. Natężenie przepływu:

$$
Q=\frac{\Pi \cdot d^{2}}{4} \cdot V\left[\mathrm{~m}^{3} \cdot \mathrm{s}^{-1}\right]
$$

Z obliczeń hydraulicznych modernizowanego odcinka kanalizacji przy grawitacyjnych warunkach pracy wynika, że tylko między studniami deszczowymi SD2-SD3 i SD3-SD4 (rys. 5) połączonymi przewodami o średnicy $d=0,3 \mathrm{~m}$, natężenia przepływu $q_{2-3}$ i $q_{3-4}$ nie spełniają warunków przepływu grawitacyjnego, tj.: $q_{2-3}=0,120 \mathrm{~m}^{3} \cdot \mathrm{s}^{-1}>Q_{o}=0,095$ $\mathrm{m}^{3} \cdot \mathrm{s}^{-1}$ oraz $q_{3-4}=0,129 \mathrm{~m}^{3} \cdot \mathrm{s}^{-1}>Q_{o}=0,0956 \mathrm{~m}^{3} \cdot \mathrm{s}^{-1}$ (tab.).

Na odcinkach tych określono prędkości przepływu i objętości natężenia przepływu w warunkach pod ciśnieniem. Sposób obliczeń polegał na ustaleniu różnicy rzędnych spiętrzenia wody górnej i dolnej w studniach deszczowych SD2 i SD3 (rys. 8). Z obliczeń hydraulicznych wynika, że wysokość spiętrzenia wody dolnej, która spełnia warunki projektowanego natężenia przepływu wynosi $\mathrm{w}$ studni SD2 0,6 m, a w studni SD3 0,8 m (tab.). Odpowiednie prędkości przepływu i objętości natężenia przepływu zawierają się w przedziale: SD2-SD3 $\rightarrow V_{o}=$ $=1,712 \mathrm{~m} \cdot \mathrm{s}^{-1}, Q_{o}=0,121 \mathrm{~m}^{3} \cdot \mathrm{s}^{-1}>0,1199 \mathrm{~m}^{3} \cdot \mathrm{s}^{-1}$ oraz 
SD3-SD4 $\rightarrow V_{o}=1,953 \mathrm{~m} \cdot \mathrm{s}^{-1}, Q_{o}=0,138 \mathrm{~m}^{3} \cdot \mathrm{s}^{-1}>$ $>0,129 \mathrm{~m}^{3} \cdot \mathrm{s}^{-1}(\mathrm{tab})$.

\section{Czas opróżnienia kanalizacji deszczowej}

Obliczenia czasu opróżnienia $(T)$ analizowanego wariantu modernizowanej kanalizacji deszczowej przeprowadzono dla przypadku nadzwyczajnego, który zakłada całkowite napełnienie zbiorników retencyjnych i studni deszczowych istniejących. Obliczenia wykonano dla przewodu kanalizacji o najmniejszej średnicy $d=0,3 \mathrm{~m}$, według wzoru.

$$
T=\frac{2 \cdot D^{2} \cdot \sqrt{H-h}}{d^{2} \cdot \sqrt{\frac{2 \cdot \mathrm{g}}{1+\xi_{w l}+\frac{8 \cdot \mathrm{g}}{c^{2}} \cdot \frac{L}{d}}}}[\mathrm{~s}]
$$

gdzie:

$D$ - suma średnic studni retencyjnych i studni kanalizacji deszczowej [m];

$d$ - najmniejsza średnica przewodu kanalizacji deszczowej $[\mathrm{m}]$;

$H$ - wysokość spiętrzenia wody górnej [m];

$h$ - wysokość spiętrzenia wody dolnej [m];

c - współczynnik prędkości według Manninga [-],

$L$ - długość kanalizacji deszczowej [m].

$$
\begin{aligned}
& T=\frac{2 \cdot\left(1,2^{2} \cdot 14+2,5^{2} \cdot 5 \cdot 0,4 \cdot \sqrt{3,28-0,4}\right)}{0,3^{2} \cdot \sqrt{\frac{2 \cdot 9,81}{1+0,5+\frac{8 \cdot 9,81}{58,98^{2}} \cdot \frac{264}{0,3}}}}= \\
& =2021,9 \mathrm{~s}=33,7 \mathrm{~min}
\end{aligned}
$$

Z obliczeń hydraulicznych wynika, że po zakończeniu opadu zbiorniki retencyjne i studnie kanalizacji deszczowej opróżnione będą po około $34 \mathrm{~min}$.

\section{PODSUMOWANIE I WNIOSKI}

Analiza zakresu i przyczyn podtopień obiektów budowlanych oraz terenów przyległych bezodpływowej zlewni wód opadowych i roztopowych w obrębie ulicy Podborskiej w Warszawie, analiza inwentaryzacji dotychczasowych rozwiązań, wyników badań geotechnicznych, pomiarów niwelacyjnych oraz wyników obliczeń meteorologicznych, hydrologicznych i hydraulicznych pozwoliły na sformułowanie następujących wniosków:

1. Najniżej położone miejsce analizowanej zlewni znajduje się w ulicy Podborskiej, która obejmuje część ulic Borsuczej i Zbąszyńskiej oraz przyległe działki z projektowanymi dwoma blokami mieszkalnymi.

2. Teren zlewni poprzecinany jest wyrobiskami po wyeksploatowanych glinach pylastych, zasypanych po 1945 roku odpadami z odgruzowywania Warszawy.

3. Zlewnia obecnie odwadniana jest dwoma wpustami deszczowymi zlokalizowanymi w ulicy Podborskiej z odprowadzeniem ścieków deszczowych do otwartego zbiornika retencyjnego i trzech studni retencyjnych. Pojemność zbiorników wynosi $156,9 \mathrm{~m}^{3}$; są one opróżniane samochodami cysternami z wywozem do miejsca zrzutu.

4. Opad o wysokości $30,8 \mathrm{~mm}$, czasie trwania $40 \mathrm{~min}$ i objętości $278,92 \mathrm{~m}^{3}$, który wystąpił w tym rejonie, podtopił fragment jezdni i chodników do wysokości $0,35 \mathrm{~m}$.

5. W ramach rozwiązania problemów podtopień w analizowanej zlewni, zaproponowano dwie koncepcje odwodnienia.

Pierwsza koncepcja składa się z dwu sposobów ujęcia wód, które działać będą jednocześnie. Pierwszym sposobem jest budowa zbiornika retencyjnego otwartego lub krytego o objętości $225 \mathrm{~m}^{3}$, do którego będą odprowadzane ścieki deszczowe głównie z jezdni, chodników i parkingów przydomowych. Wadą tego rozwiązania jest konieczność opróżniania zbiornika za pomocą samochodów cystern, podobnie jak miało to miejsce przy zbiorniku istniejącym. Drugim sposobem jest odprowadzenie wód opadowych z odwodnienia dachów dwu projektowanych budynków mieszkalnych do gruntu za pomoca dwu studni chłonnych o wydatkach $3,32 \cdot 10 \mathrm{~m}^{3} \cdot \mathrm{s}^{-1} \mathrm{każda}$.

Koncepcja druga polega na ujęciu wód deszczowych w ulicy Podborskiej za pomocą istniejących 
wpustów deszczowych i włączeniu jej do systemu odwodnienia parkingu budynku biurowego przyległego do działek inwestycyjnych. Wody deszczowe z parkingu odprowadzone będą do kolektora głównego o średnicy $1 \mathrm{~m}$ znajdującego się w alei Krakowskiej. Kanalizacja po modernizacji ma długość $264 \mathrm{~m}$ i zmienną średnice przewodów rurowych, które kolejno wynoszą; 0,5;0,3;0,4 m. Ostatnie 29 m odcinka kanalizacji o średnicy $0,4 \mathrm{~m}$ położonego pod aleją Krakowską będzie wymieniona na przewody o średnicy $0,8 \mathrm{~m}$ za pomocą metody przewiertu bezwykopowego. W skład kanalizacji wchodzi 10 studni deszczowych o średnicy $1,2 \mathrm{~m}$, pięć studni retencyjnych o średnicy $2,5 \mathrm{~m}$ oraz separator substancji ropopochodnych przeznaczony do wymiany.

6. Obliczenia hydrauliczne kanalizacji wykonano dla opadu o prawdopodobieństwie $20 \%$, czasie trwania $15 \mathrm{~min}$ i natężeniu deszczu $131 \mathrm{dcm}^{3} \cdot \mathrm{s}^{-1} \cdot \mathrm{ha}^{-1}$. $\mathrm{W}$ tych warunkach system działać będzie grawitacyjnie za wyjątkiem dwu odcinków przewodu o średnicy $0,3 \mathrm{~m}$, w których przepływ będzie pod ciśnieniem.

7. Zaproponowano trzy sposoby odwodnienia analizowanej zlewni: zbiornik retencyjny otwarty ścieków deszczowych; studnie chłonne wód opadowych z odwodnienia dachów; kanalizację deszczową ścieków deszczowych z odprowadzeniem do istniejącej zmodernizowanej sieci kanalizacji deszczowej. Z wymienionych sposobów odwodniania zbiornik retencyjny wymaga opróżniania za pomocą pojazdów asenizacyjnych.

8. Z zaproponowanych sposobów odwodnienia przyjęto do realizacji wariant odwodnienia za pomocą zmodernizowanej kanalizacji deszczowej. W przypadku budowy nowych obiektów budowlanych i zwiększeniu ilości ścieków zaleca się kolejną modernizację. Proponuje się wymianę przewodów kanalizacji parkingu o średnicy 0,3 i $0,4 \mathrm{~m}$ na przewody o średnicy $0,5 \mathrm{~m}$, zmianę separatora substancji ropopochodnych na bardziej nowoczesny, zastapienia przewodu o średnicy $0,4 \mathrm{~m}$ pod aleją Krakowską przewodem o średnicy $0,8 \mathrm{~m} \mathrm{z}$ wykorzystaniem metody bezwykopowej.

\section{PIŚMIENNICTWO}

Baszcz, M. (2017). Zastosowanie modelu SWMM do obliczenia przepływów i ich redukcji przez zbiorniki na obszarze lotniska Chopina. Acta Scientiarum Polonorum Architectura, 16 (1), 79-91.

Edel, R. (2006). Odwodnienie dróg. Warszawa: Wydawnictwo Komunikacji i Łączności.

Koda, E., Matusiewicz, W. i Osiński, P. (2017). Niesprawność systemów odwadniajacych $w$ obiektach budowlanych. W Awarie budowlane: zapobieganie, diagnostyka, naprawy, rekonstrukcje (strony 411-422). Szczecin: Wydawnictwo ZUT.

Kotowski, A. (2011). Podstawy bezpiecznego wymiarowania odwodnień terenów. Warszawa: Wydawnictwo Seidel-Przywecki.

Kubrak, E. i Kubrak, J. (2000). Hydraulika techniczna: przykłady obliczeń. Warszawa: Wydawnictwo SGGW.

Lechowicz, Z., Garbulewski, K., Król, P., Matusiewicz, W. i Wrzesiński, G. (2014). Damage to road excavation slopes due to groundwater flow. W Proceedings of the $X V$ Danube - European Conference on Geotechnical Engineering, Vienna. T. 1 (strony 571-576).

Matusiewicz, W. (2003a). Działanie systemu kanalizacji deszczowej w zlewni miejskiej w warunkach deszczu nawalnego. Acta Scientiarum Polonorum, Architectura, 2, 83-95.

Matusiewicz, W. (2003b). Zabezpieczenie obiektów budowlanych przed skutkami deszczów nawalnych w warunkach ograniczonego odpływu. Przeglad Techniki Rolniczej i Leśnej, 2, 22-27.

Matusiewicz, W. (2011). Zagrożenia bezpieczeństwa budowli w wyniku nieprawidłowych metod odwodnienia. Przeglad Naukowy - Inżynieria i Ksztaltowanie Środowiska, 54, 344-354.

Mielcarzewicz, E. (1990). Odwadnianie terenów zurbanizowanych i przemystowych: systemy odwadniania. Warszawa, PWN.

PN-B-02480:1986. Grunty budowlane. Określenia, symbole, podział i opis gruntów.

PN-B-04481:1988. Grunty budowlane. Badania próbek gruntu.

PN-EN ISO 14688-2:2006. Badania geotechniczne. Oznaczanie i klasyfikowanie gruntów. Część 2: Zasady klasyfikowania. + PN-EN ISO 14688-2:2006/Ap2:2012.

Sokołowski, J. i Żbikowski, A. (1993). Odwodnienia budowlane i osiedlowe. Warszawa: Wydawnictwo SGGW.

Wiłun, Z. (2013). Zarys geotechniki. Warszawa: Wydawnictwa Komunikacji i Łączności. 


\section{DRAINAGE OF THE DEPRESSION AREA IN A SMALL URBAN CATCHMENT}

\section{ABSTRACT}

Depression area in a small urban catchment without the possibility of outflow piles up surface waters from precipitation, causing flooding. The extent of flooding depends on the intensity of rain, the size of the urban catchment and the rainwater receiver. One of the methods of drainage is the accumulation of water in retention reservoirs, and then transporting them into the receiver as in the case of the central part of Podborska Street in Warsaw. This solution is not very effective because it requires continuous emptying of the retention reservoir. Two alternative solutions have been proposed. The first one consists in the outflow of clean water to the ground, and rainwater to a new reservoir on the other side of the street. The second one provides for the outflow of all rainwater from the catchment to the existing rainwater drainage of the car park and the administration building, as well as the construction of new retention reservoirs connected with a $0.5 \mathrm{~m}$ diameter pipe with an existing retention system. The rainwater from reservoirs will flow through the rainwater drainage of the car park and separator of petroleum substances with bypass to the existing storm sewer system located in Krakowska Avenue. Existing storm sewer pipe with a diameter of $0.4 \mathrm{~m}$, located under a two-lane road is connected to the storm sewer system with a diameter of $1.0 \mathrm{~m}$. In order to eliminate the flow intensity under Krakowska Avenue, it was proposed to replace the $0.4 \mathrm{~m}$ diameter section with a diameter of $0.8 \mathrm{~m}$ in order to allow more water to flow out in the future. The pipe replacement will be carried out using trenchless technology, i.e. concrete pipes will be removed from the ground under the roadway by hydraulic cylinders. On the other side of the street with simultaneous removal of existing pipes, the hole will be widened with a horizontal non-steered drilling with a diameter of $0.9 \mathrm{~m}$ and, at the same time, new pipes with a diameter of $0.8 \mathrm{~m}$ will be pressed.

Key words: flood, drainage, storm sewer, depression area, small urban catchment 